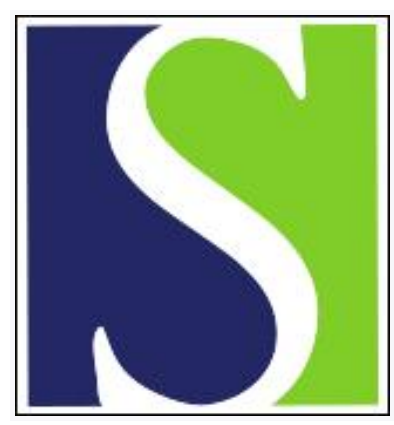

Scand J Work Environ Health 1998;24(5):386-391

https://doi.org/10.5271/sjweh.359

Issue date: Oct 1998

\title{
Cancer mortality of art glass workers in Tuscany, Italy
}

by Pirastu R, Bartoli D, Battista G, De Santis M, laia T, Orsi D, Valiani M, Tarchi M

Key terms: glassworker, maker and former; larynx cancer; lung cancer

This article in PubMed: www.ncbi.nlm.nih.gov/pubmed/9869310

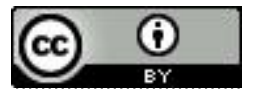




\title{
Cancer mortality of art glass workers in Tuscany, Italy
}

\author{
by Roberta Pirastu, MSc, ${ }^{1,4}$ Dusca Bartoli, MD, ${ }^{2}$ Giuseppe Battista, MD, ${ }^{3}$ Marco De Santis, BSc, ${ }^{4}$ Tonina \\ laia, MD, ${ }^{2}$ Daniela Orsi, DSc, Marzia Tarchi, MD, ${ }^{2}$ Mauro Valiani, MD ${ }^{2}$
}

Pirastu R, Bartoli D, Battista G, De Santis M, laia T, Orsi D, Tarchi M, Valiani M. Cancer mortality of art glass workers in Tuscany, Italy. Scand J Work Environ Health 1998;24(5):386-391.

\begin{abstract}
Objectives This study considers the cause-specific mortality from cancer among art glass workers employed in 17 industrial facilities in Tuscany, Italy.

Methods A cohort of 3390 workers, 3180 men and 210 women, employed at least 1 year, was taken from company payrolls. It was followed between the year each factory started operation, mostly the mid-1950s, and 31 December 1993. The cause-specific expected mortality from cancer was computed for men relative to Tuscany rates, specified for gender, 5-year age groups, and calendar year. Separate analyses were carried out for the job title of maker and former and for batch mixers.

Results For $3180 \mathrm{men}$, the observed mortality was above the expected for larynx [standardized mortality ratio (SMR) 166, 90\% confidence interval (90\% CI) 90 282], lung (SMR 123, 90\% CI 100-151), stomach (SMR 105, 90\% CI 76-142), and brain (SMR 150, 90\% CI 71-282) cancer. Increases for these causes were also found for the makers and formers. Mortality from larynx and lung cancer increased with latency, and significantly increased SMR values were observed for $\geq 21$ years since first exposure. The increasing pattern was also present after adjustment for smoking.

Conclusions The results showed consistently increased mortality from larynx and lung cancer in the overall cohort and among makers and formers. Stomach and brain cancer was also increased in the overall cohort and among the makers and formers.
\end{abstract}

Key terms glassworkers, larynx cancer, lung cancer, makers and formers.

Employment in the art glass industry entails exposure to definite and probable lung carcinogens, such as silica, arsenic, cadmium, nickel, and asbestos (1), as well as to lead, which has been recently suggested as a human carcinogen in the occupational setting on the basis of convincing evidence for lung and kidney cancer (2). Other chemical hazards include exposure to polycyclic aromatic hydrocarbons, a mixture of probable and possible carcinogens (3), and sulfuric acid, evaluated as carcinogenic for the lung and larynx in strong inorganic acid mists (4). In addition antimony, a possible human carcinogen (5), and hydrogen fluoride, with burning and irritative effects on the respiratory system, are used in glassworks (6). Heat and noise are additional health hazards existing in this work environment.

Among glassworkers a higher-than-expected mortality has been documented for cancer of the lung (7-10) and larynx (7). Increased cancer risk has been shown for the stomach $(10-13)$, colon $(12,14)$, urogenital organs (11), bladder (15), skin (10), and brain (16-19), and there is also an increased risk for lymphohemopoietic malignancies (20). An excess mortality from cardiovascular diseases has also been observed $(9,11,12)$.

According to the International Agency for Research on Cancer (IARC), the manufacture of art glass entails exposures that are probably carcinogenic to humans, this industry was therefore allocated to IARC's cancer classification of group 2A (21). The epidemiologic evidence for the evaluation was based primarily on the association with lung cancer, consistently shown across cohort studies and also observed in case-referent investigations, together with the finding of an increased risk of stomach cancer in several cohort and case-referent studies.

The present investigation was carried out to determine whether there was any increased cause-specific mortality for glassworkers in general and for the job title of

1 Università "La Sapienza" (University of Rome "La Sapienza"), Roma, Italy.

2 Azienda USL n. 11 (Local Health Unit N11), Toscana, Italy.

3 Università di Siena (University of Siena), Siena, Italy.

4 Istituto Superiore di Sanità (National Health Institute), Roma, Italy.

Reprint requests to: Ms Roberta Pirastu, c/o Istituto Superiore di Sanità Laboratorio di Igiene Ambientale, Viale Regina Elena 29900161 Roma, Italy. [E-mail: pirastu@pop3.iss.it] 
makers and formers and for batch mixers in particular The present article focuses on mortality from malignant diseases, whereas mortality from nonmalignant diseases is the subject of a separate contribution (22).

\section{Subjects and methods}

\section{Subjects}

The eligibility criterion for the subjects was employment for at least 1 year in any of the 17 factories active on 31 December 1991 in the Tuscany area considered in this study. Meeting this criterion were 3390 subjects, 3180 men and 210 women, but the analysis was restricted to men. In addition, 2434 persons who held the job title of maker and former were considered separately. In this report the 2 groups have been referred to as the total cohort and the makers, respectively. A separate analysis was also completed for the subgroup of 259 batch mixers.

The subjects were identified from payroll lists, an independent and complete source of individual data. Individual data on job history for year of start and termination of employment were abstracted from the payrolls for each job title.

Table 1 shows that the total cohort and makers contributed, respectively, 74759 and 57925 person-years of observation. The distribution of person-years by age and duration of employment is also shown. Batch mixers accumulated 4997 person-years of observation, about $20 \%$ being less than 40 years of age and more than a third having more than 10 years of exposure.

\section{Information on causes of death}

For all the subjects not active in any of the 17 factories at the end of the follow-up (31 December 1993), vital status was ascertained through the National Death Index for 1980-1987, the Regional Death Index for 19861993, and the registrar's office at the place of residence or death (1950-1985). Ascertainment of vital status was completed for $96 \%$ of the cohort. In the case of the registrar's office the cause of death had been coded by a trained nosologist. The cohort members not traced through the Registrar's office at the place of residence or of birth were assumed alive to be at the end of the follow-up.

All 3 sources had adopted the rules of the revision of the International Classification of Diseases (ICD) current at the time of death. An evaluation of the 2 indices has documented the accuracy and agreement between them (25); the agreement with the coding from the nosologists was satisfactory for all the categories of causes of death, apart from the violent ones.

\section{Exposure}

In the area considered in this study, the maximum number of employees in art glass production, about 3500 , was reached in the 1960s; the total number of employees in 1996 was approximately 800 , factory size ranging between 15 and 120 workers. The start of operation of the factories ranged between 1949 and 1985; in only 1 factory was crystal produced. The final products include tableware, glass containers, lighting glass, and ornamental glass.

Table 2 shows the consumption in 1996 of substances of toxicologic relevance in the factories included in the study. The consumption of arsenic trioxide decreased from 47500 to $14828 \mathrm{~kg} /$ year in $1991-1996$. The use of arsenic began in 1960, in response to the request for colored glass from the United States market. In that period, mechanized processes were introduced and arsenic was used as a fining agent. In tools and furnaces, asbestos was present until 1990 when substitution by fiber glass and ceramics fiber-glass material was implemented; the asbestos consumption in 1985 , similar to that of

Table 1. Cohort characteristics by vital status at the end of the follow-up and the person-years distribution by time variables.

\begin{tabular}{|c|c|c|c|c|}
\hline & \multicolumn{2}{|c|}{ Total cohort } & \multicolumn{2}{|c|}{$\begin{array}{l}\text { Makers and } \\
\text { formers }\end{array}$} \\
\hline & $\mathrm{N}$ & $\%$ & $\mathrm{~N}$ & $\%$ \\
\hline \multicolumn{5}{|l|}{ Vital status } \\
\hline Alive & 2561 & . & 1964 & . \\
\hline $\begin{array}{l}\text { Deceased } \\
\text { With cause of death } \\
\text { Without cause of death }\end{array}$ & $\begin{array}{r}488 \\
477 \\
11\end{array}$ & . & $\begin{array}{r}364 \\
357 \\
7\end{array}$ & . \\
\hline Lost to follow-up & 131 & 4 & 106 & 4 \\
\hline Total & 3180 & . & 2434 & \\
\hline $\begin{array}{l}\text { Total person-years } \\
\text { Age }\end{array}$ & 74759 & . & 57925 & . \\
\hline $\begin{array}{l}<40 \text { years } \\
40-65 \text { years } \\
>65 \text { years }\end{array}$ & $\begin{array}{r}34112 \\
34943 \\
5704\end{array}$ & $\begin{array}{r}46 \\
47 \\
7\end{array}$ & $\begin{array}{r}28764 \\
25204 \\
395\end{array}$ & $\begin{array}{l}50 \\
44 \\
76\end{array}$ \\
\hline \multicolumn{5}{|l|}{ Work experience } \\
\hline $\begin{array}{l}\leq 10 \text { years } \\
>10 \text { years }\end{array}$ & $\begin{array}{l}56386 \\
18373\end{array}$ & $\begin{array}{l}75 \\
25\end{array}$ & $\begin{array}{l}45109 \\
12816\end{array}$ & $\begin{array}{l}78 \\
22\end{array}$ \\
\hline \multicolumn{5}{|l|}{ Latency } \\
\hline $\begin{array}{l}>20 \text { years } \\
\leq 20 \text { years }\end{array}$ & $\begin{array}{l}19637 \\
55122\end{array}$ & $\begin{array}{l}26 \\
74\end{array}$ & $\begin{array}{l}15271 \\
42654\end{array}$ & $\begin{array}{l}27 \\
73\end{array}$ \\
\hline
\end{tabular}

Table 2. Consumption of substances of toxicologic relevance in Tuscany glassworks, 1996.

\begin{tabular}{lrc}
\hline Substance & Amount $(\mathrm{kg})$ & Number of factories \\
\hline Silica sand & 3194000 & 9 \\
Antimony trioxide & 5225 & 6 \\
Arsenic trioxide & 14828 & 5 \\
Antimony-based fining agents & 84000 & 4 \\
Lead & & $1^{\text {a }}$ \\
\hline
\end{tabular}

a Crystal glassworks. 
previous years, was $3446 \mathrm{~kg}$. In 1990 , measurements of asbestos during its substitution in tools showed a concentration of 300 fibers per liter for the operator and 50 fibers per liter for those working at a distance of about 3 meters (23).

In a few of the glassworks included in this study, air and biological measurements were taken in 1994-1995; no measurements were made in previous years. The air measurements from factories using arsenic as a fining agent showed that the arsenic concentration ranged from 11 to $172 \mu \mathrm{g} / \mathrm{m}^{3}$, with most samples above $10 \mu \mathrm{g} / \mathrm{m}^{3}$, the threshold limit value of the American Conference of Governmental Industrial Hygienists (ACGIH-TLV). A speciation analysis showed that $12 \%$ was inorganic arsenic, $64 \%$ was in methylated forms, and $23 \%$ was from dietary intake. Exposure to silica decreased over time, as shown by measurements in the early 1980s and in the early 1990 s after the implementation of dust control measures. The average concentration of respirable quartz in the first period was $0.5 \mathrm{mg} / \mathrm{m}^{3}$, above the ACGIH-TLV of $0.1 \mathrm{mg} / \mathrm{m}^{3}$, but it was below this limit in the second period (24).

The job title of maker and former is the only job title entailing contemporary exposure to all the chemicals used in this industry, a mixture of agents evaluated as certain and probable human carcinogens such as arsenic, silica, lead, and asbestos. During forming, glass objects are formed from molten glass by blowing, casting, and pressing. Mouth blowing is the classic method in the fabrication of art glass objects. Hand-forming operations are partially automated, and the glassblower blows gobs of the proper viscosity into molds. Deep items are formed by blowing glass into molds with compressed air. Pressing is used for flat items.

A separate analysis was also completed for the subgroup of 259 batch mixers because their task is predominantly manual and involves exposure to dusts of the majority of glass batch components.

\section{Smoking}

Cross-sectional information on the smoking habits of 377 male glassworkers was available from interview data collected in the early 1990s during periodic medical examinations. These data allowed the computation of smoking-adjusted standardized mortality ratios for lung and larynx cancer; the smoking-adjusted expected number of cases was derived under the assumption of a 10 -fold increase for ex-smokers and a 20 -fold increase for smokers using the procedure described by Axelson (27).

\section{Risk estimates}

Standardized mortality ratios (SMR) were computed using the Occupational Cohort Mortality Analysis Program (OCMAP) (26), and mortality rates for the residents of Tuscany were applied for comparison. For each SMR value, a $90 \%$ confidence interval $(90 \% \mathrm{CI})$ was calculated on the assumption of a Poisson distribution.

\section{Results}

Table 3 lists the causes of death and the SMR values for the total cohort and for the makers. The mortality from all causes was lower than expected for the total cohort and the makers. The same was seen for malignant neoplasms in the total cohort, while, for the makers, mortality from malignant neoplasms was somewhat increased. Several noncancer causes of mortality showed an excess both for the total cohort and the makers, namely, hypertension, pneumoconiosis, and diseases of the genitourinary system.

Mortality from malignant neoplasms was increased for cancer of the stomach (total SMR 105, 90\% CI 76142; makers' SMR $107,90 \%$ CI 71-153), melanoma (total SMR 212, 90\% CI 58-547; makers' SMR 294, 90\% CI 80-761), kidney (total SMR 119, 90\% CI 47-251; makers' SMR 137, 90\% CI 47-314), brain (total SMR 150 90\% CI 71-282; makers' SMR 209 90\% CI 98393), and leukemia (total SMR $12190 \%$ CI 57-227; makers' SMR 143 90\% CI 62-282). The observed mortality from cancer of the larynx was above the expected (total SMR 166, 90\% CI 90-282; makers' SMR 193, 90\% CI 96-348), and a statistically significant increase was found for lung cancer (total SMR $123,90 \%$ CI $100-$ 151; makers' SMR 143, 90\% CI 113-178). In the subgroup of 281 makers who had the specific task of glassblower, 1 case of larynx cancer was observed versus 0.5 expected and 6 cases of lung cancer were observed versus 4 expected.

Table 4 shows the mortality pattern for cancers of the larynx and lung by time since first exposure for the overall cohort and for the makers, with and without adjustment for smoking. For the overall cohort and the makers the SMR values increased with latency for both larynx and lung cancer. For 20 years of latency the increase in risk was statistically significant for lung cancer for the overall cohort and for both larynx and lung cancer among the makers. The pattern of increasing SMR values with increasing latency was still present when the SMR values were adjusted for smoking, although no longer significant in the highest latency category.

In the subgroup of 259 batch mixers, not shown in the table, 50 deaths occurred (SMR 99, 90\% CI 78126). The SMR values were greater than unity for lung cancer (SMR 159, 90\% CI 80-269, 9 cases) and for cerebrovascular disease (SMR 106, 90\% CI 42-222, 5 cases). 
Table 3. Mortality by cause in the total cohort and in the group of makers and formers, the regional population being used as reference. $(0=$ observed deaths, SMR = standardized mortality ratio, $90 \% \mathrm{Cl}=90 \%$ confidence interval $)$

\begin{tabular}{|c|c|c|c|c|c|c|}
\hline \multirow[t]{2}{*}{ Cause of deatha } & \multicolumn{3}{|c|}{ Total cohort } & \multicolumn{3}{|c|}{ Makers \& formers } \\
\hline & 0 & SMR & $90 \% \mathrm{Cl}$ & 0 & SMR & $90 \% \mathrm{Cl}$ \\
\hline All causes $(001-999)$ & 488 & 90 & $83-97$ & 364 & 96 & $88-105$ \\
\hline Malignant neoplasms (140-208) & 183 & 96 & $85-109$ & 137 & 103 & $88-119$ \\
\hline Digestive organs $(150-9)$ & 59 & 82 & $65-102$ & 38 & 76 & $57-99$ \\
\hline $\begin{array}{l}\text { Stomach (151) } \\
\text { Intestine (152) } \\
\text { Colon (153) } \\
\text { Liver (155) }\end{array}$ & $\begin{array}{r}30 \\
6 \\
6 \\
6\end{array}$ & $\begin{array}{r}105 \\
66 \\
100 \\
64\end{array}$ & $\begin{array}{l}76-142 \\
29-130 \\
44-198 \\
28-127\end{array}$ & $\begin{array}{r}21 \\
4 \\
4 \\
4\end{array}$ & $\begin{array}{r}107 \\
63 \\
97 \\
62\end{array}$ & $\begin{array}{r}71-153 \\
22-144 \\
33-22 \\
21-142\end{array}$ \\
\hline Respiratory organs $(160-5)$ & 80 & 123 & $102-149$ & 64 & 143 & $115-176$ \\
\hline $\begin{array}{l}\text { Larynx (161) } \\
\text { Lung (162) }\end{array}$ & $\begin{array}{l}10 \\
70\end{array}$ & $\begin{array}{l}166 \\
123\end{array}$ & $\begin{array}{r}90-282 \\
100-151\end{array}$ & $\begin{array}{r}8 \\
56\end{array}$ & $\begin{array}{l}193 \\
143\end{array}$ & $\begin{array}{r}96-348 \\
113-178\end{array}$ \\
\hline Bladder (188) & 5 & 68 & $27-144$ & 4 & 80 & $27-182$ \\
\hline Kidney $(189)$ & 5 & 119 & $47-251$ & 4 & 137 & $47-314$ \\
\hline Nervous system (190-2) & 8 & 157 & $78-284$ & 8 & 219 & $109-395$ \\
\hline Brain (191) & 7 & 150 & $71-282$ & 7 & 209 & $98-393$ \\
\hline Site unspecified (195-9) & 4 & 71 & $24-161$ & 2 & 50 & $9-158$ \\
\hline Lymphatic and hematopoietic tissue $(200-8)$ & 12 & 95 & $55-154$ & 8 & 88 & $44-160$ \\
\hline Leukemia $(204-8)$ & 7 & 121 & $57-227$ & 6 & 143 & $62-282$ \\
\hline Other neoplasms & 34 & 75 & $55-100$ & 18 & 75 & $49-112$ \\
\hline Nervous system diseases $(320-359)$ & 4 & 50 & $17-114$ & 4 & 70 & $24-159$ \\
\hline Circulatory system diseases (390-459) & 154 & 82 & $71-93$ & 107 & 83 & $70-97$ \\
\hline $\begin{array}{l}\text { Hypertension }(400-404) \\
\text { Ischemic heart diseases }(410-414) \\
\text { Cerebrovascular disease }(430-438)\end{array}$ & $\begin{array}{l}10 \\
53 \\
41\end{array}$ & $\begin{array}{r}178 \\
67 \\
77\end{array}$ & $\begin{array}{r}96-301 \\
53-84 \\
58-100\end{array}$ & $\begin{array}{r}7 \\
35 \\
30\end{array}$ & $\begin{array}{r}182 \\
64 \\
83\end{array}$ & $\begin{array}{r}85-341 \\
47-85 \\
59-112\end{array}$ \\
\hline Respiratory system diseases $(460-519)$ & 32 & 99 & $72-133$ & 26 & 118 & $83-164$ \\
\hline Pneumoconiosis $(500-505)$ & 7 & 200 & $94-376$ & 6 & 250 & $109-493$ \\
\hline Digestive system diseases $(520-579)$ & 19 & 51 & $34-75$ & 17 & 66 & $42-99$ \\
\hline Liver cirrhosis (571) & 13 & 55 & $33-87$ & 11 & 67 & $37-110$ \\
\hline Genitourinary system diseases (580-629) & 11 & 169 & $95-279$ & 10 & 224 & $121-380$ \\
\hline Accidents and violence $(800-999)$ & 51 & 102 & $80-128$ & 37 & 98 & $73-129$ \\
\hline Missing ICD codes & 11 & & & 8 & & \\
\hline Other causes & 18 & 164 & $103-243$ & 7 & 111 & $52-209$ \\
\hline
\end{tabular}

a Code of the International Classification of Diseases (ICD) in parentheses.

Table 4. Mortality from larynx and lung cancer among the glass workers by time since first exposure without (SMR vithout $_{1}$ and with $\left(\mathrm{SMR}_{\text {with }}\right)$ smoking adjustment, the regional population being used for reference. $(0=$ observed number of deaths, SMR $=$ standardized mortality ratio)

\begin{tabular}{|c|c|c|c|c|c|c|c|c|c|c|c|c|}
\hline \multirow{3}{*}{$\begin{array}{l}\text { Time since } \\
\text { first exposure }\end{array}$} & \multicolumn{6}{|c|}{ Total cohort } & \multicolumn{6}{|c|}{ Makers \& formers } \\
\hline & \multicolumn{3}{|c|}{ Larynx cancer } & \multicolumn{3}{|c|}{ Lung cancer } & \multicolumn{3}{|c|}{ Larynx cancer } & \multicolumn{3}{|c|}{ Lung cancer } \\
\hline & 0 & $S M R_{\text {without }}$ & $\mathrm{SMR}_{\text {with }}$ & 0 & $\mathrm{SMR}_{\text {without }}$ & $\mathrm{SMR}_{\text {with }}$ & 0 & $\mathrm{SMR}_{\text {without }}$ & $\mathrm{SMR}_{\text {with }}$ & 0 & SMR $_{\text {without }}$ & $\mathrm{SMR}_{\text {with }}$ \\
\hline$\leq 10$ years & 1 & 78 & 63 & 8 & 76 & 62 & 0 & & & 7 & 95 & 78 \\
\hline $11-20$ years & 3 & 155 & 130 & 20 & 112 & 92 & 3 & 221 & 176 & 16 & 126 & 103 \\
\hline$\geq 21$ years & 6 & 215 & 176 & 42 & $149^{a}$ & 122 & 5 & $263^{a}$ & 217 & 33 & $172^{\mathrm{a}}$ & 140 \\
\hline Total & 10 & 166 & 137 & 70 & $123^{a}$ & 101 & 8 & 193 & 157 & 56 & $143^{a}$ & 119 \\
\hline
\end{tabular}

a Lower $90 \%$ confidence limit greater than 100 .

\section{Discussion}

The mortality results of this cohort of Italian glassworkers confirm those of earlier epidemiologic investigations, mainly from cancer of the lung and larynx. An increased risk from stomach and brain cancer was also found.
The "healthy worker effect", as a decreased overall mortality, was not evident in this cohort. Permanence of healthier persons at work, which could partially account for the healthy worker effect, was presumably less likely for this skilled work force than in large-scale industries. Regional rates were used for comparison, possibly adjusting for geographic variation in mortality. 
The increment in lung cancer risk has been observed among glassworkers in previous studies $(9-11,28,29)$. Occupational exposure both to arsenic among smelters $(30-32)$ and to lead and lead compounds (2) has been associated with increased lung cancer mortality. Other known lung carcinogens are also present in glassworks, namely, asbestos and antimony $(3,33,34)$.

Glass polishing and matting entails exposure to sulfuric acid, which is considered carcinogenic in strong inorganic acid mists. Epidemiologic evidence has documented a significantly increased risk for larynx cancer (4). Asbestos exposure in the occupational setting has also been associated with larynx cancer (3).

Adjustment for smoking, a major confounding factor for larynx and lung cancer, did not substantially change the results.

The slight increase from stomach cancer, adjusted for the elevated mortality in Tuscany by the use of regional rates, although based on small numbers, is a finding common to that of other investigations, specifically for glassblowers, who are a subgroup of makers $(11,12)$. A role of lead exposure in stomach carcinogenesis was recently suggested $(35,36)$. The contamination of blowpipes by heavy metals and the possibility of an oral route of exposure for the larynx, lung, and stomach has been hypothesized for glassblowers $(12,37)$. Preliminary measurements of metals (arsenic, cadmium, copper, chromium, and lead) in blowpipes from this study show a tendency for the metal concentration to stay in the upper part of the pipe, closer to the mouth, and to decrease gradually along the pipe itself.

The increase of brain cancer in this study appears in a perspective of inconsistent results for this cancer site among glassworkers. Some authors have reported an increase (16-19), while others have not $(7,10-12,38)$. Exposures occurring in glassworks, such as asbestos (39) and more recently lead (40), have also been suggested as risk factors for brain cancer. Epidemiologic studies have so far been unable to isolate effects attributable to specific exposures in causing brain cancer (41). Furthermore, none of the chemical exposures reported as associated with increased risk, such as organic solvents, lubricating oils, polycyclic aromatic hydrocarbons (42), although present, are either predominant or characteristic of the glass industry.

The excess of leukemia and kidney cancer was based on few cases and therefore does not allow any interpretation. However previous studies of employment in glassworks have found increased mortality for leukemia (20). Kidney cancer has been found to be associated with exposure to arsenic $(43,44)$ and more recently to lead $(2)$.

In summary, the results of this study showed consistently increased mortality for larynx and lung cancer in the overall cohort and for makers and formers. The find- ings do not point to a definite connection between cancer risk and specific exposures, a not uncommon situation with epidemiologic observations. It should be noted that the health hazards observed among Tuscany glassworkers are consistent both with those of glassworkers in other countries and with carcinogenic effects detected in association with exposure to various metallic compounds present in glassworks. A comprehensive safety and health intervention program, with the aim of reducing hazardous exposure and of monitoring the health status of glassworkers, has already been adopted (45), and its beneficial effects will be appreciable in the planned extension of the follow-up.

\section{Acknowledgments}

We thank Dr Gun Wingren and Professor Olav Axelson, who first studied the art glass industry in Sweden and encouraged us to do the same in Italy. We acknowledge the support and helpful comments of Dr Pietro Comba.

This work was funded in part by Regione Toscana Project $274 / \mathrm{C}$, deliberation $342 / 94$ and by the National Research Council Project "Clinical Applications of Oncologic Research".

\section{References}

1. Steenland K, Loomis D, Shy C, Simonsen N. Review of occupational lung carcinogens. Am J Ind Med 1996;29:47490.

2. Vainio H. Lead and cancer - association or causation? [editorial]. Scand J Work Environ Health 1997;23:1-3.

3. International Agency for Research on Cancer (IARC). Overall evaluation of carcinogenicity: an updating of IARC monographs vol 1-42. Lyon: IARC, 1987. IARC monographs on the evaluation of carcinogenic risks to humans, suppl 7.

4. International Agency for Research on Cancer (IARC). Occupational exposures to mists and vapours from strong inorganic acids and other industrial chemicals. Lyon: IARC, 1992:106. IARC monographs on the evaluation of carcinogenic risks to humans, vol 54.

5. International Agency for Research on Cancer (IARC). Some organic solvents, resin monomers and related compounds, pigments and occupational exposures in paint manufacture and painting. Lyon: IARC, 1989. IARC monographs on the evaluation of carcinogenic risks to humans, vol 47.

6. National Institute for Occupational Safety and Health (NI$\mathrm{OSH}$ ). Criteria for a recomended standard: occupational exposure to hydrogen fluoride. Washington (DC): US Department of Health, Education and Welfare, 1976. Publication no $76-143$.

7. Cordioli G, Cuoghi L, Solari PL, Berrino F, Crosignani P, Riboli E. Mortality from tumors in a cohort of workers in the glass industry. Epidemiol Prev 1987;30:16-18.

8. Neurberger M, Kundi M. Occupational dust exposure and 
cancer mortality-results of a prospective cohort study. In Simonato L, Fletcher AC, Saracci R, Thomas DL, editors. Occupational exposure to silica and cancer risk. Lyon: International Agency for Research on Cancer (IARC), 1990:6573. IARC scientific publications, no 97.

9. Wingren G, Englander V. Mortality and cancer morbidity in a cohort of Swedish glassworkers. Int Arch Occup Environ Health 1990;62:253-7.

10. Sankila R, Karjalainen S, Pukkala E, Oksanen H, Hakulinen $\mathrm{T}$, Teppo $\mathrm{L}$, et al. Cancer risk among glass factory workers: an excess of lung cancer? Br J Ind Med 1990;47:815-8.

11. Wingren $\mathrm{G}$, Axelson $\mathrm{O}$. Mortality pattern in a glass producing area in SE Sweden. Br J Ind Med 1985;42:411-4.

12. Wingren $\mathrm{G}$, Axelson $\mathrm{O}$. Mortality in the Swedish glassworks industry. Scand J Work Environ Health 1987;13:412-6.

13. Siemiatycki J, editor. Risk factors for cancer in the workplace. Boca Raton (FL): CRC Press, 1991.

14. Wingren G, Englander V. Mortality and cancer morbidity in a cohort of Swedish glassworkers. Int Arch Occup Environ Health 1990;62:253-7.

15. Dolin PJ. A descriptive study of occupation and bladder cancer in England and Wales. Br J Cancer 1992;65:476-8.

16. Englund A, Ekman G, Zabrielski L. Occupational categories among brain tumor cases recorded in the cancer registry in Sweden. Ann NY Acad Sci 1981;381:188-96.

17. McLaughlin JK, Malker HSR, Blot WJ, Malker BK, Stone BJ, Weiner JA, et al. Occupational risks for intracranial gliomas in Sweden. JNCI 1987a;78:253-7.

18. McLaughlin JK, Thomas TL, Stone BJ, Blot WJ, Malker HSR, Weiner JA et al. Occupational risks for meningiomas of the CNS in Sweden. J Occup Med 1987b;29:66-68.

19. Mallin K, Rubin M, Joo E. Occupational cancer mortality in Illinois white and black males, 1979-84, for seven cancer sites. Am J Ind Med 1989;15:699-717.

20. Hours M, Fevotte J, Ayzac L, Danache B, Bergeret A, Milan $\mathrm{JJ}$, et al. Exposition professionelles et hémopathies malignes une enquete cas-tèmoins réalisée à Lyon (France). Rev Epidémiol Santé Publique 1995;43:231-41.

21. International Agency for Research on Cancer (IARC). Beryllium, cadmium, mercury, and exposure in the glass manufacturing industry. Lyon: IARC, 1993:371. IARC monographs on the evaluation of carcinogenic risks to humans, vol 58.

22. Bartoli D, Battista G, De Santis M, Iaia TE, Orsi D, Tarchi M, et al. Cohort study of art glass workers in Tuscany, Italy: mortality from nonmalignant diseases. Occup Med. In press.

23. Baldacci M, Bartoli D, Chambry L, Giusti S, Silvestri S. La sostituzione dell'amianto nel comparto vetro: un'esperienza di prevenzione. Rass Med Lavoratori 1991;20:42-6.

24. Fornaciai S, Giusti S, Zingoni A. Diciotto anni di monitoraggi del quarzo nelle vetrerie: valutazione dei risultati. In: Bartoli D, Iaia TE, Zingoni A, Valiani M, editors. Proceedings of the international meeting Technology, Health Hazards and Prevention in the Art Glass Industry, May 14-16 1997, Empoli, pg. $39-40$.

25. Lagorio S, Forastiere F, Michelozzi P, Perucci CA, Altavista $P$, Costa $G$, et al. Accertamento delle cause di morte in studi di follow-up: confronto di procedure utilizzabili in Italia. Epidemiol Prev 1987;31:57-61.

26. Marsh GM, Preinenger M. OCMAP: a user oriented occupational cohort mortality analysis program. Am Stat 1980;34:245-6.

27. Axelson O. Aspects on confounding in occupational health epidemiology [letter to the editor]. Scand J Work Environ Health 1978;4:98-102

28. Lynge E, Kurppa K, Kristofersen L, Malker H, Sauli H. Silica dust and lung cancer: results from the Nordic occupational mortality and cancer incidence registers. JNCI 1986;77:8839.

29. Levin LI, Zheng W, Blot WJ, Goa YT, Fraumeni JF. Occupation and lung cancer in Shanghai: a case-control study. Br J Ind Med 1988;45:450-8.

30. Pershagen $G$. Lung cancer mortality among men living near an arsenic-emitting smelter. Am J Epidemiol 1985;122(4):684-94.

31. Axelson O, Dahlgren E, Jansson CD, Rehnlund SO. Arsenic exposure and mortality: a case-referent study from a Swedish copper smelter. Br J Ind Med 1978;35:8-15.

32. Enterline PE, Day R, Marsh G. Cancers related to exposure to arsenic at a copper smelter. Occup Environ Med 1995;52:2832.

33. Jones RD. Survey of antimony workers: mortality 19611992. Occup Environ Med 1994;51:772—6.

34. Schnorr TM, Steenland, Thun MJ, Rinsky RA. Mortality in a cohort of antimony smelter workers. Am $\mathbf{J}$ Ind Med 1995;27:759-70.

35. Fu H, Boffetta P. Cancer and occupational exposure to inorganic lead compounds: a meta-analysis of published data. Occup Environ Med 1995;52:73-81.

36. Gerhardsson L, Hagmar L, Rylander L, Skerving S. Mortality and cancer incidence among secondary lead smelter workers. Occup Environ Med 1995;52:667-72.

37. Andersson $\mathrm{L}$, Wingren $\mathrm{G}$, Axelson $\mathrm{O}$. Some hygienic observations from the glass industry. Int Arch Occup Environ Health 1990;62:253-7.

38. Wingren G, Axelson O. Cluster of brain cancers spuriously suggesting occupational risk among glassworkers. Scand J Work Environ Health 1992;18:85—9.

39. Seidman H, Selikoff IJ, Hammond EC. Mortality of brain tumors among asbestos insulation workers. Ann NY Acad Sci 1982;381:160-71.

40. Antilla A, Heikkilä P, Nykyry E, Kauppinen T, Pukkala E, Hernberg $S$, et al. Risk of nervous system cancer among workers exposed to lead. J Occup Environ Health 1996;38:131-6.

41. Inskip PD, Linet MS, Heineman EF. Etiology of brain tumors in adults. Am J Epidemiol 1995;17(2):362-414.

42. Thomas TL. Primary brain tumors associated with chemical exposure. In: Bleeker ML, Hansen JA, editors. Occupational neurology and clinical neurotoxicology. Baltimore (MA): Williams \& Wilkins, 1994:187-206.

43. Wu MM, Kuo TL, Hwang YH, Chen CJ. Dose-response relation between arsenic concentration in well water and mortality from cancerr and vascular diseases. Am J Epidemiol 1989;130:1123-32.

44. Enterline PE, Day R, Marsh GM. Cancers related to exposure to arsenic at a copper smelter. Occup Environ Med 1995;52:28-32.

45. Bartoli D, Iaia TE, Zingoni A, Valiani M, editors. Proceedings of the international meeting Technology, Health Hazards and Prevention in the Art Glass Industry, May 14-16 1997, Empoli.

Received for publication: 24 October 1997 